\title{
The Effect of Financial Development on Poverty and Inequality in African Countries
}

\author{
By \\ Babajide Fowowe \\ Department of Economics \\ University of Ibadan, Nigeria. \\ babafowowe@hotmail.com \\ and \\ Babatunde Abidoye \\ Department of Agricultural Economics, Extension and Rural Development \\ University of Pretoria \\ babidoye@up.ac.za
}

\begin{abstract}
Understanding the factors that are important in determining poverty and inequality is one of the steps in the fight to eradicate poverty in the world. This is particularly so for African countries because when compared to other regions, Africa has the largest concentration of people living below the poverty line. This article examines the effect of financial development as measured by private credit and broad money (M2) on poverty and inequality in African countries. The empirical results indicate that financial development has not had a significant effect on poverty and inequality in African countries. Macroeconomic variables such as low inflation and trade openness were found to be statistically significant, implying that they can help reduce the level of poverty and inequality. Our results confirm the deficiencies in African financial systems and highlight the fact that more efforts need to be done to improve access of poor households and SMEs to financial services.
\end{abstract}

Keywords: Africa, Financial Development, Poverty, Inequality

JEL Classification: C33, E44, O55, I32 


\section{The Effect of Financial Development on Poverty and Inequality in African Countries}

\section{Introduction}

Research into the role that the financial sector plays in promoting economic growth has proliferated in the past quarter of a century ${ }^{1}$. The conclusions from most of these studies are that financial development enhances economic growth and consequently, policies that lead to a deepening of the financial sector have been advocated. Financial systems perform a number of functions through which they foster faster economic growth. Levine (2005) identifies five of such ways in which the financial sector enhances growth: (i) the mobilization and pooling of savings; (ii) helping to trade, hedge, and pool risk; (iii) monitoring firms and exerting corporate governance; (iv) producing information and allocating capital; and (v) easing the exchange of goods and services. Through these functions, the financial systems are able to attract deposits and ensure a better and more efficient allocation of resources which lead to growth of the economy.

Despite the numerous empirical investigations into the impact of financial development on growth, there is still a dearth of empirical research into how a more developed financial sector contributes to the reduction of poverty and inequality. There seems to be an implicit assumption in existing research that if financial development improves growth, then this automatically translates into a reduction in poverty and inequality. However, this is not necessarily true, for example, income distribution could be worsened and result in a disproportionate percentage of the gains from growth being transferred to the non-poor ${ }^{2}$. Also, as has been well documented, financial liberalizations have been identified as causes of financial crisis and an unstable macroeconomic environment (Kaminsky and Reinhart, 1999), and these have been identified as detrimental to the poor (Easterly and Fischer, 2001). World Bank (2001b) identifies three crucial areas for accessing the impact of finance on economic performance which are: its contribution to economic growth; its contribution to poverty reduction; and its ability to lead to

\footnotetext{
${ }^{1}$ Levine (2005) provides a comprehensive survey of both theoretical and empirical studies of the finance-growth nexus.

${ }^{2}$ Notwithstanding this fact, the bulk of existing empirical studies find that economic growth is pro-poor (Dollar and Kraay, 2002; Kraay, 2004; Besley and Burgess, 2003). World Bank (2001b:36) concludes that the empirical evidence is against a trade-off between faster economic growth and a worsening of income distribution.
} 
economic stability. Besley and Burgess (2003) also posit that economic growth is not a sufficient condition for achieving the Millennium Development Goal (MDG) of halving global poverty, and that poverty can still be reduced in the absence of faster growth. They therefore advocate the development of other policy and institutional changes (financial development included) that can directly reduce poverty. In light of these therefore, it is important to examine separately the effects of financial development on reducing poverty and inequality.

The empirical literature on the effects of financial development on poverty and inequality is quite small when compared with that on financial development and economic growth. Some of the few studies we are aware of include Honohan (2004), Jeanneney and Kpodar (2005), Beck, Demirguc-Kunt and Levine (2007), Jalilian and Kirkpatrick (2005), Clarke, $\mathrm{Xu}$ and Zou (2003), and Quartey (2005). The main conclusions from these studies are that the deepening of the financial sector leads to a reduction in poverty and inequality. Of all these studies, however, only one (Quartey, 2005) examines an African country. It is typical for researchers to lump developing and developed countries together. A study that examines how financial development has affected poverty for a broad group of countries in Africa would be particularly insightful.

One of the justifications for this is the high level of disparity in terms of the ratio of population living below the \$1-a-day line between Sub-Saharan African (SSA) countries and other regions of the world (Besley and Burgess, 2003). In addition to this, Ram (1999), Andersen and Tarp (2003), and Jalilian and Kirkpatrick (2005) criticized the assumption of structural homogeneity made by cross-country studies and assert that running regressions using data for countries with different levels of development, that are also from different regions could lead to misleading results. Ram (1999) tests the validity of such assumptions by re-estimating the King and Levine (1993) equations and splitting the samples into low-growth, mid-growth and high-growth samples, while also running regressions for the full sample. Their results for the full sample and high-growth sample show a positive and significant coefficient for financial development but it is negative and insignificant for the low- and mid-growth samples. Andersen and Tarp (2003) also re-estimate the Levine, Loayza and Beck (2000) equations by splitting the sample 
according to regions ${ }^{3}$. The results agree with Ram (1999) because for the full sample, financial development is positive and significant but its coefficient loses significance and eventually becomes negative as successive regions are excluded.

What we have done in this paper is to conduct an econometric analysis of the effect of financial sector development on poverty and inequality in Africa. This is the first study we are aware of that has used data for a group of African countries to examine the relationship between financial development, poverty and inequality.

The rest of this paper is organized as follows: the next section provides an overview of the channels through which a developed financial sector is expected to affect poverty and inequality. Section 3 gives a brief background of financial development in SSA countries. The model is presented in section 4 and section 5 presents the estimation method and data description. The results of our empirical tests are presented in section 6 . The final section provides the conclusion and policy implications.

\section{The Links between Financial Development, Poverty and Inequality}

The discussion in this section provides a review of the positive and negative links between financial development, poverty and inequality. The positive relationship between financial development, poverty and inequality could either be direct or indirect. The direct link refers to how the benefits of financial sector development are transferred to reducing poverty and income inequality while the indirect link shows how financial deepening exerts a positive effect on economic growth, and how the gains from growth are channelled to the reduction of poverty and inequality. The discussion in this section proceeds as follows: we first provide an overview of the direct links between financial development and poverty; thereafter we review the indirect links; and the final paragraph presents how financial development can negatively affect poverty and inequality.

There are a number of ways through which finance can directly affect poverty and inequality. First, the development of the financial sector can ease the credit constraints hitherto faced by poor households and which limited their abilities to undertake

\footnotetext{
${ }^{3}$ The authors note that splitting the sample according to growth experience as done by Ram (1999) could present a selectivity problem.
} 
productive investment. Increased access to credit has the implication that poor households can now spend more on consumption and improve their welfare. Also, since they do not need to rely on self-finance they can raise capital from financial intermediaries to engage in productive activities. On the down-side however, finance can have a debilitating impact on the poor if access to credit is limited to wealthy households thereby resulting in their incomes rising while those of the poor fall. In such a case, income inequality will increase. A related argument involves the work of Greenwood and Jovanovic (1990) who show that the relationship between income inequality and financial development takes an inverted-U-shaped curve. According to them, in the early stages of development, the poor will not be able to afford the initial set-up costs associated with accessing financial intermediaries and thus the benefits of enhanced financial intermediation will be felt only by the rich. This would result in a widening of income inequality and it is only over time that the poor will be able to afford such costs and access intermediaries. A similar scenario would happen if lending rates are high as this would restrict the numbers of the poor obtaining credit. For the few poor people that take out credit at high rates, there is the danger of moral hazard and adverse selection problems which would increase financial fragility.

In addition to this, the broadening of the financial sector and subsequent entrance of new players enhances competition between financial intermediaries (Beck, Demirguc-Kunt and Levine, 2007). The banking systems in many developing countries are oligopolistic where a few banks virtually control all assets and face little or no competition. The increased competition in the financial sector as a result of financial development leads to a provision of better services and financial products which will improve the quality of lives of poor households.

Furthermore, because financial intermediaries help to pool and limit risk, the problems of asymmetric information peculiar to financial markets are reduced and this results in a more stable macroeconomic environment which is beneficial to the poor. The special skills that financial intermediaries have of collecting information and monitoring borrowers will ensure that small-scale businesses who obtain loans are advised on best 
accounting practices and realistic business plans ${ }^{4}$. A developed financial system would also lead to better loan recovery rates because of an advanced supervisory and monitoring capacity.

Another channel through which financial development can directly affect poverty and inequality relates to the abilities of bigger and more powerful financial intermediaries to bear the high costs of small credits (Rajan and Zingales, 2001). Chigumira and Masiyandima (2003) note that lending to the poor is more costly than to the rich and consequently, the marginal cost of lending to the poor is higher than that of lending to the rich (p.28). The financial intermediaries could bear such costs with the long-run in view assuming small and medium scale enterprises will graduate into large scale businesses in the future.

The indirect link between financial development, poverty and inequality reduction is through the effect of finance on economic growth. The expected positive effects of a developed financial sector on economic growth have long been outlined (Schumpeter, 1912; McKinnon, 1973; Shaw, 1973; Galbis, 1977; World Bank, 1989; Pagano, 1993; Levine, 2005). One of the ways in which financial development enhances growth is through the mobilization of funds from inefficient to efficient uses. Financial intermediaries that increase and operate under better conditions are able to channel funds efficiently from savers to investors in a cheap and efficient way. In addition, well functioning financial intermediaries are able to attract more savings thereby increasing the possibility of channelling more funds for investment. A developed financial sector also facilitates trading, hedging, pooling and the diversification of risk, which allows the establishment of large projects that may have been impossible in its absence. The traditional role of financial institutions of liquidity creation by borrowing from savers on a short-term basis and lending to investors on a long-term basis provides another channel through which they foster economic growth. By bringing savers and investors together, financial intermediaries are able to reduce transactions and information costs. Such a positive relationship between economic growth and financial development is supported

\footnotetext{
${ }^{4}$ This becomes very important in light of the fact that many small and medium scale enterprises do not have comprehensive business plans which leads to misapplication of loans in many cases (Amonoo et al., 2003, p.22). Amonoo et al. (2003) reports that about 26\% of small business respondents do not keep records of any kind and only a similar percentage have business plans. Also, almost half (42\%) of respondents had not undergone any form of training by attending workshops or seminars.
} 
by a lot of empirical studies (King and Levine, 1993; De Gregorio and Guidotti, 1995; Levine, Loayza and Beck, 2000; Beck, Levine, and Loayza, 2000). These studies report a positive and significant coefficient for various indicators of financial development ${ }^{5}$.

An indirect link between financial development and poverty can be assumed if financial development improves economic growth, and consequently, economic growth reduces poverty. Economic growth has been identified as a powerful force for poverty and inequality reduction and it has been observed that richer countries experience a fall in poverty (World Bank, 2001a). Economic growth can reduce poverty either directly or indirectly (Arestis and Caner, 2004). Growth can impact directly on the poor by increasing the factors of production that they own and improving conditions in the sectors and regions where they live. There will be a reduction in inequality because the indirect benefits help in redistributing the higher incomes from growth and come from increased government revenues which are used for transfer payments and improving the resources of the poor. The empirical studies show that growth is beneficial to the poor (Dollar and Kraay, 2002; Besley and Burgess, 2003; Kraay, 2004).

Despite the benefits to be gained from a developed financial system, there are a number of criticisms of financial development as an instrument for poverty and inequality reduction. One of such criticisms centres on the fact that financial development is synonymous with developing and attracting savings into formal financial institutions to the detriment of informal financial markets. But such measures could have adverse consequences for the poor due to the fact that informal markets are better placed to serve the needs of the poor (Chigumira and Masiyandima, 2003) and they traditionally finance all investment projects (Lensink, 1996). If financial reforms lead to a disproportionate development of formal financial markets, this could cause a substantial decline in credit available to the poor. Another point to note is that lending interest rates have been observed to increase when financial reforms are implemented. Increasing cost of funds discourages the poor from borrowing and crowds them out of the market for loanable

\footnotetext{
${ }^{5}$ However, there is an increasing number of empirical studies that find that finance does not exert such a strong and positive effect on economic growth (Rousseau and Wachtel, 2005; Ram, 1999; Andersen and Tarp, 2003; Favara, 2003). Other studies show that the development of the financial sector through financial liberalisation leads to financial fragility and banking crises (Demirguc-Kunt and Detragiache, 1999; Kaminsky and Reinhart, 1999); while still some studies claim that such crises only last in the short-run and financial development is growth-enhancing in the long-run (Kaminsky and Schmukler, 2002; Tornell and Westermann, 2004).
} 
funds. Formal financial intermediaries are also known for demanding stringent lending criteria such as collateral and information on past business records. Most poor households cannot fulfill such criteria and are consequently discriminated against and refused credit by banks. Furthermore, even in cases where financial intermediaries relax their lending criteria and are prepared to lend to the poor, in most cases the poor do not have enough information pertaining to the availability of loans and how to access them, thereby limiting the ability of financial development in reducing poverty and inequality.

\section{The African Story ${ }^{6}$}

Sub-Saharan African countries like many countries of the world have gone through series of policies geared towards higher sustainable economic growth and improved welfare for its citizenry. However, some of these policies took them far away from these goals. The history of financial development in these countries captures aptly these failed policy thrusts.

Following the end of the colonial era in the 1960s, the financial sectors in these countries were heavily regulated. This became necessary given that the formal financial sectors were inefficient in providing credit to all sectors and areas of the country. In particular, the few banks at that period were mainly located in the urban areas and other sectors that were deemed unpromising were largely not extended credits by the banks. This led to a high level of disparity in the growth of the sectors and also widened the disparity in the rural-urban areas. Government regulation and nationalization of the financial industry including direct government intervention in credit allocation by the financial sectors were some of the tools used to alleviate these problems. However, these policies led to financial repression and curtailed the growth of the sector (Gelbard and Leite, 1999).

Following the seminal works by McKinnon (1973) and Shaw (1973), many African countries adopted some form of financial liberalization. The common elements of the financial liberalization efforts included the following: bank denationalization and

\footnotetext{
${ }^{6}$ The discussion in this section draws from Fowowe (forthcoming).
} 
restructuring; interest rate liberalization; abolition of directed credit; strengthening of central banks, and development of financial markets.

The liberalization of interest rates has been a major component of financial liberalization measures all over the world and Africa has not been an exception in this regard. Examples of removals of interest rate controls include partial liberalization of interest rates by the regional Central Bank of West African States (BCEAO) ${ }^{7}$ in 1989 and full liberalization in 1993. The regional Bank of Central African States (BEAC) ${ }^{8,9}$ liberalized interest rates in 1990. A number of countries commenced liberalization of interest rates in the 1980s such as South Africa in 1982, Gambia, Ghana and Zambia in 1985, Burundi and Botswana in 1986, Nigeria and Malawi in 1987, and Kenya and Zimbabwe in 1991.

Major restructuring and re-capitalization of banks occurred in Cote d'Ivoire, Senegal, Republic of Congo, Cameroon, The Gambia, and Ghana. In Kenya a major restructuring plan of the financial sector started in 1988 while in Madagascar, bank restructuring took place in 1988 and 1989, and in addition to this, privatization of banks also took place with the enactment of a new banking law to end the government's domination of banks and also to allow the entry of foreign investors. The liquidation of banks has also been implemented in the financial reforms carried out in SSA. Comprehensive bank liquidation was carried out in Senegal and this resulted in the closing down of 7 banks (out of 15). In The Gambia, the Agricultural Development Bank was liquidated in 1989. In Mauritius, the Bank of Mauritius closed the Mauritius Co-operative Central Bank Limited (MCCB) in April 1996 and the Union International Bank Limited (UIB) had its doors closed in May 1996. In Uganda following the comprehensive restructuring of banks embarked upon after liberalization, insolvent banks were closed down.

Directed credit has been another major form of financial repression in Africa. Directed credit schemes were detrimental in two ways: (i) only businesses that were friendly with the government could have access to credit; (ii) banks did not make meaningful returns on credit because of the low rate of interest. The elimination of directed credit during

\footnotetext{
${ }^{7}$ BCEAO is the Central Bank for the West African Economic and Monetary Union whose members are: Benin, Burkina Faso, Cote d'Ivoire, Guinea-Bissau, Mali, Niger, Senegal and Togo.

${ }^{8}$ BEAC is the Central Bank for the Central African Economic and Monetary Union whose members are: Cameroon, Central African Republic, Chad, Republic of Congo, Equatorial Guinea and Gabon.

${ }^{9}$ The 14 countries of the WAEMU and CAEMC form the CFA franc zone.
} 
financial liberalization is supposed to correct these deficiencies. Countries which abolished directed credit allocations in the 1980s include Nigeria in 1985, Ghana in 1988, BCEAO countries in 1989. The countries that abolished directed credit in the 1990s include the BEAC countries in 1990, Gambia in 1990, Malawi and Zimbabwe in 1991, and Mauritius in 1992.

The financial liberalization episodes embarked upon in Africa have also included measures aimed at granting Central Banks autonomy and power to regulate financial markets. Strengthening of prudential regulation started in the BCEAO zone with the introduction of a new reserve requirements ratio of $1.5 \%$ for banks and $5 \%$ for financial institutions. It was also made mandatory for banks to get approval from the BCEAO for loans exceeding a specified level and a new body - the Banking Control Commission was established to further strengthen prudential regulation and supervision. The countries that made major regulatory changes include Ghana, Kenya, Malawi, Mauritius, Nigeria, South Africa, Uganda, and Zambia. Such measures at enhancing prudential regulation included revision and enactments of Banking Laws, establishment of Deposit Insurance Corporations, increase in minimum paid up capital of banks, and some measures of independence of central banks from the Ministries of Finance.

Figure 1 presents a graph of the level of financial development for five regions ${ }^{10}$ including SSA countries as measured by private credit as a ratio of GDP using data from Beck, Demirguc-Kunt and Levine (2007). The figure shows no significant change in the level of financial development for SSA countries despite the adoption of financial liberalization. SSA countries have the lowest level of financial development relative to other regions. The countries in the Middle East and North Africa have also grown higher in terms of financial depth than the SSA countries since 1993.

Despite the high regulation and subsequent financial liberalization, banks and other formal financial institutions in SSA impose stringent regulation on credit to individuals and small scale firms. High collateral values are required for loans to individuals which results in a very slim likelihood of access to credit by the poor. This led to the development of the informal institutions and cooperative societies including esusu

\footnotetext{
${ }^{10}$ High income countries were excluded from the groups used in the analysis.
} 
collectors (Soyibo, 1995 and Soyibo, 1996). These institutions primarily extend credit to individuals for consumption purposes and small scale businesses. Given this peculiarity of the SSA economy, it is very likely that informal institutions play a major role in influencing how financial development affects the income of the poor.

Similar story can be told of the level of poverty in the SSA countries. The percentage of the population living in households below poverty line has been relatively stagnant and high (Figure 2). This is in contrast to East Asia and the Pacific where the level of poverty has been falling since 1981. SSA countries also have the largest mean distance below the poverty line as a proportion of the poverty line as shown in Figure 3.

The above evidence shows that the incidences of poverty and inequality have been higher in African countries than other middle and low income countries. It is also seen that African countries have lower financial depth than other regions. Given that financial development has been identified as an important factor in the reduction of poverty and inequality (Beck, Demirguc-Kunt and Levine, 2007; Jalilian and Kirkpatrick, 2005; Clarke, Xu and Zou, 2003; Quartey, 2005), it would be insightful to ascertain the

relationship between financial development, poverty and inequality in Africa. This would have important implications for policy. A significant relationship between financial development and reduction of poverty and inequality will indicate that more conscious efforts should be channelled into the development of financial markets in Africa so as to reduce poverty and inequality.

\section{Model}

In this section, we propose 2 models that capture the dynamic behaviours of (i) poverty and (ii) inequality; conditional on the level of financial development and other control variables. In light of this, we follow the papers of Beck, Demirguc-Kunt and Levine (2007) and Dollar and Kraaowest income quintile and also measure inequality as the growth of the Gini coefficient.

Formally, we assume that the outcome of interest for country $i$ at a given period $t$ depends on the initial value of the outcome plus some control variables and an error term. 
This results in a poverty growth equation of the form:

$$
\dot{y}^{p}{ }_{i t}=\delta y^{p}{ }_{i, t-1}+x_{i t}^{\prime} \beta+c_{i}+\varepsilon_{i t}
$$

for $i=1, \ldots, N$ and $t=2, \ldots, T$. Where $\dot{y}^{p}$ it is the log difference in the poverty measure, $y^{p}{ }_{i, t-1}$ is the log of initial level of poverty measure, and $x_{i t}$ is a vector of control variables including the level of financial development. The sum of the unobserved country-specific effects $\left(c_{i}\right)$ and idiosyncratic shocks $\left(\varepsilon_{i t}\right)$ represents the decomposition of the error term.

In a similar manner, we have an inequality growth equation of the form:

$$
\dot{\mathrm{z}}^{g}{ }_{i t}=\delta \mathrm{z}^{g}{ }_{i, t-1}+x_{i t}^{\prime} \beta+d_{i}+v_{i t}
$$

where $\dot{z}^{g}{ }_{i t}$ is the log difference in the inequality measure, $z^{g}{ }_{i, t-1}$ is the log of initial level of inequality measure, and $x_{i t}$ is as previously defined. The sum of the unobserved country-specific effects is given by $\mathrm{d}_{i}$ while $v_{i t}$ gives the idiosyncratic shocks.

In line with the economic growth literature and literature on poverty, the variables that are included in the vector $x_{i t}$ are used to control for other factors that can affect poverty and inequality growth. These control variables include the level of trade openness as measured by the sum of exports and imports as share of GDP, the growth rate of the GDP deflator over the sample period as an indicator of the rate of inflation and performance of the economy, level of initial life expectancy as a measure of initial human capital and socio-economic characteristics of the country and population growth.

\section{Estimation Method and Data Description}

\subsection{Model Estimation Method}


Over the last two decades, there has been immense development in the methods used to analyze panel data that are dynamic in nature. Dynamic panel model is widely applied to data on the study of growth patterns due to the limitations in the use of existing models. The application of ordinary least squares and fixed effects models have been criticized given that the nature of the data can result in the violation of some of the assumptions of these methods. Some of the most prominent of these issues include the introduction of lagged dependent variable into the model that captures the full history of the variables in the model and small sample size issues which can lead to inconsistent estimates.

Generalized Method of Moment (GMM) estimation of dynamic panel data models proposed by Holtz-Eakin, Newey, and Rosen (1988) and developed by Arellano and Bond (1991), Arellano and Bover (1995), and Blundell and Bond (1998) is one of the models used immensely in analyzing growth data recently. The model is developed to consistently analyze and estimate data with small time periods, models with independent variables that are not strictly exogenous and also data that are possibly plagued with measurement errors. This feature makes it highly attractive to practitioners estimating models for developing countries where the data might be error prone. In this paper, we apply the Systems GMM estimator of Arellano and Bover (1995) and Blundell and Bond (1998) that assumes that first differences of the instruments are uncorrelated with the fixed effects parameters which increases the number of possible instruments that can be used in estimating the parameters of the model. The GMM estimator is such that the estimates of the parameters in our model satisfy a set of moment conditions by minimizing the quadratic distance given a weighting matrix. The optimal weighting matrix for the estimator has been shown to result in the two-step GMM estimator and is asymptotically efficient (see Hansen, 1982 and Chamberlain, 1987). Following Monte Carlo studies that indicate a downward bias in estimated asymptotic standard errors of the efficient two-step GMM estimator in finite sample, Windmeijer (2000) proposed a finite sample correction of the standard errors of the parameters by estimating the additional variation that leads to the bias and accounting for it in the standard error estimation. This was shown to lead to better inference of the parameter estimates. We make use of these estimation procedures to understand the relationship between financial development and poverty in Africa. 


\subsection{Variables and Data Description}

In this study, our first outcome of interest (poverty) is evaluated by measuring poverty as the proportion of the population living on less than $\$ 1.25$ a day; and the income share of the lowest (20\%) quintile. Our second outcome of interest (inequality) is measured by using the growth of the Gini coefficient. In this section, we will describe these variables and the sources of the data.

Growth of the Proportion of the Population living below \$1.25 per day: These headcount data are derived from household surveys provided by the World Bank using a default poverty line of \$38.00 ("\$1.25 a day" line) per month at 2005 purchasing power parity (PPP). The online version of the data obtained through povcalnet, an interactive computational tool used to replicate estimates published by the World Bank's researchers was used. For African countries, this data is available for limited number of years which dictated the size of our panel data. ${ }^{11}$ There has been wide variation in the level of poverty alleviation over the years. Countries in the region of East Asia and Pacific have been a experiencing a greater reduction in the proportion of the population that are poor since 1981. This is in contrast to SSA countries where the percentage of the population living below the poverty line has been relatively stable (Figure 2).

Growth of the Income Share of the Lowest (20\%) Quintile: Following other studies (Dollar and Kraay, 2002; Beck, Demirguc-Kunt and Levine, 2007) we define the poor as the poorest $20 \%$ of the population. Then the poor are households with income level less than the income of the poorest $20 \%$ of the population. The income of the poor is given as the share of income accruing to this poorest quintile of the population. Our measure of poverty is then given as the growth of income of the poorest quintile. Given that this data is not readily available for our sample period for many of the SSA countries, we follow the procedure in Dollar and Kraay (2002). We assume a lognormal distribution for the log of per capita income with the mean as the average per capita income from household

\footnotetext{
${ }^{11}$ The data is available in three years interval from 1981 to 2005. Countries in our sample include Benin, Botswana, Burkina Faso, Burundi, Cameroon, Central African Republic, Chad, Congo Rep, Cote d'Ivoire, Ethiopia, Gabon, Gambia, Ghana, Guinea, Kenya, Lesotho, Madagascar, Malawi, Mali, Mauritania, Niger, Nigeria, Rwanda, Senegal, South Africa, Swaziland, and Togo. Other SSA countries were excluded due to data unavailability.
} 
survey in 2005 PPP and variance estimated using the properties of the lognormal distribution and the Gini coefficient. ${ }^{12}$ This assumption results in the income share of the lowest (20\%) quintile to be defined as $\Phi\left(\Phi^{-1}(0.2)\right.$ - $\left.\sigma\right)$ (Dollar and Kraay, 2002).

Growth of Gini: The data for the Gini index is also obtained from the World Bank through povcalnet. The calculation makes use of household surveys covering 116 countries between 1981 and 2005 with the 2005 PPP data derived from the results of the International Comparison Program (ICP). The procedure makes use of two alternative specifications of the Lorenz curve (general quadratic and beta Lorenz curve) in order to arrive at a better representation of the level of inequality.

Financial Development: To measure financial development, we make use of 2 variables: private credit and M2. The first variable we have used to measure financial development is private credit which is defined as the value of credit by financial intermediaries to the private sector as a ratio of the GDP. This is a widely used proxy for financial development in the literature (Beck, Demirguc-Kunt and Levine, 2007; Jalilian and Kirkpatrick, 2005). This variable has been found to have a more robust and positive effect on economic growth than other measures of financial development (Beck et al., 2000) and it is also a more reliable proxy for financial development because it shows clearly the link between financial development and economic growth (Honohan, 2004). It is a more accurate proxy of the functioning of financial development because it is a measure of the quantity and quality of investment (De Gregorio and Guidotti, 1995).

In order to test the robustness of our results, we have used another variable, M2 as a measure of financial development. M2 is the sum of money and quasi money and is defined as the sum of currency outside banks, demand deposits other than those of the central government, and the time, savings, and foreign currency deposits of resident sectors other than the central government. While private credit could be unavailable for poor households, M2 consists of savings and currency held by all members of the public and thus captures another dimension of financial intermediation that could be missing from the private credit ratio.

\footnotetext{
${ }^{12}$ The standard deviation of the distribution is defined as $\sigma=\sqrt{2} \cdot \Phi^{-1}\left(\frac{1+G / 100}{2}\right)$ with G defined as the Gini index between 0 (equality) and 100 (richest person has all the income) and $\Phi(\bullet)$ the cumulative normal distribution function.
} 
The other variables such as trade openness as measured by ratio of exports and imports in total GDP, the rate of inflation, and life expectancy rate used in our estimation are from the World Development Indicators CD-ROM 2008.

\section{Empirical Results}

\subsection{Financial Development and Poverty}

The empirical results of the relationship between financial development and poverty are presented in Tables $2-5$. This involves estimation of equation 1 and Tables $2-3$ contain results when the poverty variable is the growth of proportion of the population living below $\$ 1.25$ per day. Tables $4-5$ present the results when the poverty variable is the growth of income share of the lowest quintile. In all the system GMM estimation models, the Hansen test of over-identifying restrictions is used to test the validity of the instruments used. Also, the assumption of no second-order serial correlation for the system GMM estimator is tested and reported in the tables. These assumptions hold in all the models presented.

\subsubsection{Financial Development and Growth of the Proportion of the Population Living} Below $\$ 1.25$ per Day

In Table 2, we have the results when financial development is measured by private credit. The results from the OLS estimation are presented in column 1 while columns 2 to 4 present the results of two-step system GMM estimates. The results from column 1 show that private credit, though negatively related to the proportion of the population living below the poverty line, is not a significant determinant of poverty reduction in African countries. This result holds irrespective of the estimation technique adopted as it is seen in column 2 that when system GMM is used instead of OLS, private credit is still insignificant in affecting poverty. This result is robust to alternative model specifications as shown in columns 3 and 4 when initial life expectancy and growth in mean income are included as additional explanatory variables. Even with the addition of more explanatory variables, financial development as proxied by private credit is still insignificant in 
determining poverty. This result supports the findings from Jeanneney and Kpodar (2005) that the channel through which financial development affects poverty in developing countries probably is probably not through private credit.

Following Beck, Demirguc-Kunt and Levine (2007), we also control for the growth in mean income in order to separate the effect of financial development on poverty and growth. The results suggest that growth in mean income and subsequent economic growth is an important determinant of poverty reduction in African countries.

In the system GMM results, the initial level of headcount and level of openness show a negative coefficient for both variables. These 2 variables are significant negative in columns 2 and 3, implying that trade benefits the poor and the higher the proportion of people living below the poverty line, the higher the magnitude of the reduction in poverty headcount relative to those with low initial poverty headcount. In an unreported regression, controlling for population growth does not significantly alter our results.

We present the results for M2 as a proxy for financial development in Table 3. The results are similar to those from Table 2 as it is seen that M2 is negatively signed in all columns. However, there is a difference because M2 is statistically significant in columns 1 to 3 , although the result in column 1 is only significant at the $10 \%$ level. This shows some evidence of a link between this measure of financial development and poverty and the negative sign implies that the higher the ratio of money to GDP, the lower the growth of the proportion of the population living below $\$ 1.25$ a day. However, conditioning on this variable, we do not find enough evidence that initial headcount, level of openness and inflation influence poverty.

\subsubsection{Financial Development and Growth of Income of the Lowest Quintile:}

The results for the growth of income of the lowest quintile are presented in Tables 4 and 5. In Table 4 we have the results when private credit is the measure of financial development and it is seen that private credit though negatively signed, does not significantly affect poverty. This result confirms the findings from Table 2 that private 
credit does not significantly affect the poor in Africa. This result is robust to different estimation techniques and the inclusion of additional explanatory variables.

For the other variables, trade openness and inflation consistently show statistical significance in the various columns. Trade openness has a significant positive effect on growth of income of the poor while inflation has a significant negative effect on growth of income of the poor. These results are consistent with the findings of Beck, DemirgucKunt and Levine (2007) who found that openness reduces poverty while inflation is harmful to the poor. These results are robust when we control for per capita GDP growth and when we allow interaction between initial income of the lowest quintile and per capita GDP growth.

The results for when M2 is used as our measure of financial development, are presented in Table 5. We find that M2 does not have a significant effect on growth of income of the poor. This confirms the findings from Tables 2 to 4, that financial development has not significantly affected the poor in the selected African countries. Initial income of the lowest quintile is the only significant variable in this table.

\subsection{Financial Development and Inequality}

Tables 6 and 7 present the results of estimating the effects of financial development on inequality in these African countries. Table 6 presents the results when private credit is the measure of financial development while in Table 7, M2 is the measure of financial development. We find from both Tables that irrespective of the variable used, financial development has not had a significant effect on inequality. These results are consistent with the results from Tables 2 to 5 where it was found that financial development has not significantly affected poverty. Trade and inflation continue to significantly affect inequality.

\section{Conclusion and Policy Implications}


The primary purpose of this paper was to empirically examine the impact of financial development on poverty and inequality in African countries. Two variables were used to measure financial development: the ratio of private credit to GDP and the ratio of broad money (M2) to GDP. Our results showed that both private credit and broad money do not significantly influence poverty and inequality in African countries.

Our results have important implications for policy. Firstly, it confirms the fact that many banks in Africa prefer to invest in treasury bills rather than extend credit to borrowers (Allen, Otchere and Senbet, 2010). This has played a major role in limiting the level of private credit granted by African banks. Data from Allen, Otchere and Senbet (2010) shows that the average ratio of private credit in SSA is 17\% while it ranged between 32 and $43 \%$ for other developing regions. This implies that financial development is hampered and households do not have access to credit. A contributory factor to this phenomenon is that banks prefer the relative safety of government securities to the risks and high transaction costs of lending to the private sector. Banks avoid lending to small and medium enterprises (SMEs) because of difficulty in obtaining information for risk assessment; SMEs have small loan requirements as against the high costs of loan processing; and the perception that new SMEs are more likely to fail (Aryeetey, 1998). A possible way to correct this will be the development of credit rating agencies and better risk assessment departments in banks as this would ensure effective risk assessment of borrowers and limit the problem of moral hazard that banks are trying to avoid.

Secondly, our results highlight the fact that financial liberalization has not been able to improve credit provision in Africa. While structural adjustment has led to increased demand for finance, this demand has not been met by an increase in supply by financial intermediaries. This can be seen from data quoted by Aryeetey (1998) that many SMEs identified finance as a major constraint to expansion with over $90 \%$ of firms identifying finance as a major constraint in Senegal and about 80\% of firms identifying finance as a major constraint in Ghana. This highlights the credit gaps inherent in African financial systems (Aryeetey, 1998) where borrowers cannot obtain finance from informal markets either because their needs exceed the capacity of such informal markets or because they cannot find packages from informal lenders that suit them. Such borrowers can also not obtain finance from formal financial intermediaries because they cannot satisfy the 
stringent criteria. Measures and policies need to put in place to fill this credit gap. Such policies essentially involve forging closer links between formal and informal financial intermediaries, eliminating fragmentation in the financial markets and enhance integration and efficiency.

The low level of financial development in Africa compared with other regions also points to the fact that policies should be directed at improving financial development. Holden and Prokopenko (2001) identified a number of factors necessary for development of the financial sector. Macroeconomic stability is essential for a more developed financial sector to emerge because informational asymmetries increase if the macroeconomic environment is unstable and volatile, and this hampers development financial development. Also, there is a need for effective prudential regulation and supervision to limit the scope for excessive risk taking and foster credibility in the financial system. However, Holden and Prokopemko (2001) note that caution must be exercised in establishing rules for the behaviour of financial intermediaries so that biases are not created against rural and poor areas. Such policies that could create biases include fixed opening hours, minimum staff requirements, limitation on types of services and transactions, prevention of mobile banking. It is important that regulation is flexible and rural area friendly so that people are encouraged both to save and borrow. In line with the discussion relating to credit gap, there is a need to have specialized financial institutions which are better equipped at evaluating investment proposals of SMEs. There is a need to put in place regulations and the appropriate framework which encourage/foster the development of these institutions.

Honohan and Beck (2007) advance that if the poor are to benefit from the financial system, development of Africa's financial system must focus on 2 key areas: (i) economic growth and (ii) improving access to financial services. On the first point, many studies have shown that economic growth is pro-poor and this translates to the fact that appropriate policies should be put in place to stimulate growth. This affects the poor in two ways, firstly, growth increases income and welfare of the poor; also, growth increases demand for and provision of financial services which enhance development of the financial system. A developed financial sector can then provide essential services to the poor. On the second point, if poor households and SMEs have better and improved 
access to financial services, consumption and investment can increase thereby improving their welfare. 


\section{References}

Allen, F., Otchere, I. and Senbet, L.W. (2010) African Financial Systems: A Review, Wharton Financial Institutions Working Paper no. 10-11, Pennsylvania: Financial Institutions Center

Amonoo, E., Acquah, P.K. and Asmah, E.E. (2003) 'The Impact of Interest Rates on Demand for Credit and Loan Repayment by the Poor and SMEs in Ghana’, IFLIP Research Paper 03-10, International Labor Organization.

Andersen, T.B. and Tarp, F. (2003) 'Financial Liberalization, Financial Development and Economic Growth in LDCs', Journal of International Development, vol.15, issue2, pp.189-209.

Arellano, M., and S. Bond. (1991) 'Some tests of specification for panel data: Monte Carlo evidence and an application to employment equations'. The Review of Econometric Studies 58: 277-297.

Arellano, M. and Bover, O., (1995) 'Another look at the instrumental-variable estimation of error-components models'. Journal of Econometrics 68, pp. 29-52.

Arestis, P. and Caner, A. (2004) 'Financial Liberalization and Poverty: Channels of Influence', Levy Economics Institute Working Paper no. 411.

Aryeetey, E. (1998) Informal Finance for Private Sector Development in Africa, Background paper prepared for the 1998 African Development Report.

Beck, T., Levine, R. and Loayza, N. (2000) 'Finance and the Sources of Growth’, Journal of Financial Economics, 58, pp.261-300

Beck, T., Demirguc-Kunt, A. and Levine, R. (2007) 'Finance, Inequality and Poverty: CrossCountry Evidence’, Journal of Economic Growth, vol.12, pp.27-49

Besley, T. and Burgess, R. (2003) 'Halving Global Poverty’, Journal of Economic Perspectives, vol.17, no.3, pp.3-22.

Blundell, R., and Bond, S., (1998) 'Initial conditions and moment restrictions in dynamic panel data models’, Journal of Econometrics, Volume 87, Issue 1, 24 August, Pages 115-143.

Chamberlain, G. (1987) Asymptotic efficiency in estimation with conditional moment restrictions, Journal of Econometrics, Vol.34, Issue 3, pp.305-334

Chigumira, G. and Masiyandima, N. (2003) 'Did Financial Sector Reform Result in Increased Savings and Lending for the SMEs and the Poor?’, IFLIP Research Paper 03-7, International Labor Organization.

Clarke, G., Xu, L.C. and Zou, H. (2003)' Finance and Income Inequality: Test of Alternative Theories', World Bank Policy Research Working Paper 2984, Washington D.C.: World Bank.

De Gregorio, J. and Guidotti, P.E. (1995) 'Financial Development and Economic Growth’, World Development, vol.23, no.3, pp.433-448.

Demirguc-Kunt, A. and Detragiache, E. (1999) 'Financial Liberalization and Financial Fragility', in Annual World Bank Conference on Development Economics 1998, B. Pleskovic and J.E. Stiglitz (eds.), Washington D.C.: World Bank.

Dollar, D. and Kraay, A. (2002) 'Growth is Good for the Poor', Journal of Economic Growth, vol.7, pp.195-225.

Easterly, W. and Fischer, S. (2001) 'Inflation and the Poor', Journal of Money, Credit and Banking, vol.33, no.2, part 1, pp.160-178. 
Favara, G. (2003) 'An Empirical Reassessment of the Relationship Between Finance and Growth’, IMF Working Paper WP/03/123, Washington D.C.: International Monetary Fund.

Fowowe, B. (Forthcoming) 'Financial Liberalization in Sub-Saharan Africa: What Do We Know?', Journal of Economic Surveys.

Galbis, V. (1977) 'Financial Intermediation and Economic Growth in Less-Developed Countries: A Theoretical Approach’. Journal of Development Studies, vol. 13, pp.58-72.

Gelbard, Enrique and Pereira Leite, Sergio (1999) 'Measuring Financial Development in SubSaharan Africa’, IMF Working Paper, Vol. , pp. 1-28, 1999.

Greenwood, J. and Jovanovic, B. (1990) 'Financial Development, Growth, and the Distribution of Income’, Journal of Political Economy, vol.98, issue5, part1, pp.1076-1107.

Hansen, L.P. (1982) Large Sample Properties of Generalized Method of Moments Estimators, Econometrica, 1982, vol. 50, issue 4, pp.1029-54

Holden, P. and Prokopenko, V. (2001) Financial Development and Poverty Alleviation: Issues and Policy Implications for Developing and Transition Countries, IMF Working Paper no. WP/01/160, Washington D.C.: International Monetary Fund.

Holtz-Eakin, D., Newey, W. and Rosen, H.S., (1988) 'Estimating vector autoregressions with panel data', Econometrica 56, pp. 1371-1396

Honohan, P. (2004) 'Financial Development, Growth and Poverty: How Close are the Links?', World Bank Policy Research Working Paper 3203, Washington D.C.: World Bank.

Honohan, P. and Beck, T. (2007) Making Finance Work for Africa, Washington D.C.: World Bank.

Jalilian, H. and Kirkpatrick, C. (2005) 'Does Financial Development Contribute to Poverty Reduction?’, Journal of Development Studies, vol.41, no.4., pp.636-656.

Jeanneney, S.G. and Kpodar, K. (2005) 'Financial Development, Financial Instability and Poverty,’ CSAE Working Paper WPS/2005-09, Oxford: Centre for the Study of African Economies.

Kaminsky, G.L. and Reinhart, C.M. (1999) 'The Twin Crises: The Causes of Banking and Balance-Of-Payments Problems', The American Economic Review, vol.89, no.3, pp.473-500.

Kaminsky, G.L. and Schmukler, S.L. (2002) 'Short-Run Pain, Long-Run Gain: The Effects of Financial Liberalization’, World Bank Policy Research Working Paper no.WPS2912, Washington D.C.: World Bank.

King, R.G. and Levine, R. (1993) 'Finance and Growth: Schumpeter Might be Right', Quarterly Journal of Economics, vol.108, no.3, pp.717-737

Kraay, A. (2004) 'When is Growth Pro-Poor? Cross-Country Evidence', IMF Working Paper WP/04/47, Washington D.C.: International Monetary Fund.

Lensink, R. (1996) 'The Allocative Efficiency of the Formal versus the Informal Financial Sector’, Applied Economics Letters, vol.3, no.3, pp.163-165.

Levine, R. (2005) Finance and Growth: Theory and Evidence, in Handbook of Economic Growth, P. Aghion and S. Durlauf (eds.), vol.1, Part A, pp.865-934, The Netherlands: Elsevier Science.

Levine, R., Loayza, N. and Beck, T. (2000) 'Financial Intermediation and Growth: Causality and Causes’, Journal of Monetary Economics, 46, pp.31-77 
McKinnon, R.I. (1973) Money and Capital in Economic Development. Washington D.C.: The Brookings Institution

Pagano, M (1993) 'Financial Markets and Growth: An Overview', European Economic Review, vol.37, pp.613-622.

Povcal Net (http://iresearch.worldbank.org/PovcalNet/jsp/index.jsp).

Quartey, P. (2005) 'Financial Sector Development, Savings Mobilization and Poverty Reduction in Ghana’, UNU-WIDER Research Paper No.2005/71, Helsinki: UNU World Institute for Development Economics Research.

Ram, R. (1999) 'Financial Development and Economic Growth: Additional Evidence', The Journal of Development Studies, vol.35, no.4, pp.164-174.

Rajan, R.G. and Zingales, L. (2001) 'The Great Reversals: The Politics of Financial Development in the $20^{\text {th }}$ Century', NBER Working Paper 8178, Cambridge: National Bureau of Economic

Research.

Rousseau, P.L. and Wachtel, P. (2005) 'Economic Growth and Financial Depth: Is the Relationship Extinct Already?’, Discussion Paper No. 2005/10, Helsinki: UNU World Institute for Development Economics Research.

Schumpeter, J.A. (1912). The Theory of Economic Development: An Inquiry into Profits, Capital, Credit, Interest, and the Business Cycle. Cambridge: Harvard University Press.

Shaw, E.S. (1973) Financial Deepening in Economic Development. New York: Oxford University Press.

Soyibo, A. (1995) 'Financial Linkage and Development in Sub-Saharan African: A study of the Informal Financial Sector in Nigeria’, Working Paper 88, Overseas Development Institute, London.

Soyibo, A. (1996) 'Financial Linkage and Development in Sub-Saharan African: The Role of Formal Financial Institutions in Nigeria', Working Paper 88, Overseas Development Institute, London.

Tornell, A. and Westermann, F. (2004) 'The Positive Link Between Financial Liberalization', Growth and Crises, CESifo Working Paper no.1164.

Windmeijer, F. (2005) 'A Finite Sample Correction for the Variance of Linear Efficient TwoStep GMM Estimators’, Journal of Econometrics 126: 25-51.

World Bank (1989) World Development Report, New York: Oxford University Press.

World Bank (2001a) World Development Report 2000/2001: Attacking Poverty, New York: Oxford University Press.

World Bank (2001b) Finance for Growth: Policy Choices in a Volatile World, New York: Oxford University Press. 
Table 1 Summary Statistics

\begin{tabular}{lccccc}
\hline Variable & Obs & Mean & Std. Dev. & Min & Max \\
\hline Growth in Gini & 216 & -0.0030 & 0.0595 & -0.2626 & 0.3258 \\
GDP per capita growth & 216 & 0.0094 & 0.1199 & -0.4559 & 0.2962 \\
Growth of lowest income share & 216 & 0.0136 & 0.1225 & -0.4776 & 0.74070 \\
Growth of headcount & 216 & -0.0272 & 0.2240 & -1.3028 & 0.9997 \\
Private Credit & 216 & 0.1565 & 0.1138 & 0.0169 & 0.6539 \\
Broad Money (M2) & 216 & 22.2362 & 9.4217 & 0.9181 & 55.6594 \\
Growth of mean income & 216 & 0.0312 & 0.1778 & -0.5121 & 1.1689
\end{tabular}




\begin{tabular}{|c|c|c|c|c|}
\hline \multirow[t]{3}{*}{$\begin{array}{l}\text { Table 2: Fin } \\
\text { Headcount) }\end{array}$} & Develo & t (Private & t) and Pov & (Growth \\
\hline & (1) & (2) & (3) & (4) \\
\hline & OLS & System GMM & System GMM & System GMM \\
\hline \multirow[t]{2}{*}{ Private Credit } & -0.011 & -0.030 & -0.057 & -0.056 \\
\hline & $(0.015)$ & $(0.094)$ & $(0.087)$ & $(0.046)$ \\
\hline \multirow[t]{2}{*}{ Initial Headcount } & 0.0002 & $-0.004^{* * *}$ & $-0.003 * *$ & -0.001 \\
\hline & $(0.0003)$ & $(0.001)$ & $(0.001)$ & $(0.001)$ \\
\hline \multirow[t]{2}{*}{ Trade openness } & 0.018 & $-0.105^{*}$ & $-0.139 * * *$ & -0.019 \\
\hline & $(0.017)$ & $(0.057)$ & $(0.054)$ & $(0.09)$ \\
\hline \multirow[t]{2}{*}{ Inflation } & -0.0001 & -0.002 & -0.0002 & -0.003 \\
\hline & $(0.001)$ & $(0.005)$ & $(0.005)$ & $(0.004)$ \\
\hline Initial Life & 0.0002 & & 0.013 & 0.002 \\
\hline Expectancy & $(0.002)$ & & $(0.008)$ & $(0.005)$ \\
\hline Growth in Mean & $-1.152 * * *$ & & & $-1.489 * * *$ \\
\hline Income & $(0.206)$ & & & $(.398)$ \\
\hline \multirow[t]{2}{*}{ Constant } & -0.110 & 0.589 & -0.084 & -0.084 \\
\hline & $(0.106)$ & $(0.271)$ & $(0.597)$ & $(0.522)$ \\
\hline R-squared & 0.68 & & & \\
\hline $\mathrm{AR}(2)$ test $(\mathrm{P})$ & & 0.600 & 0.616 & 0.223 \\
\hline Hansen Test (P) & & 0.579 & 0.630 & 0.708 \\
\hline
\end{tabular}

Note: The dependent variable is growth of headcount. ***, **,* indicate significance at the $1 \%, 5 \%$ and $10 \%$ levels respectively. Standard errors reported are Windmeijer corrected Standard errors.

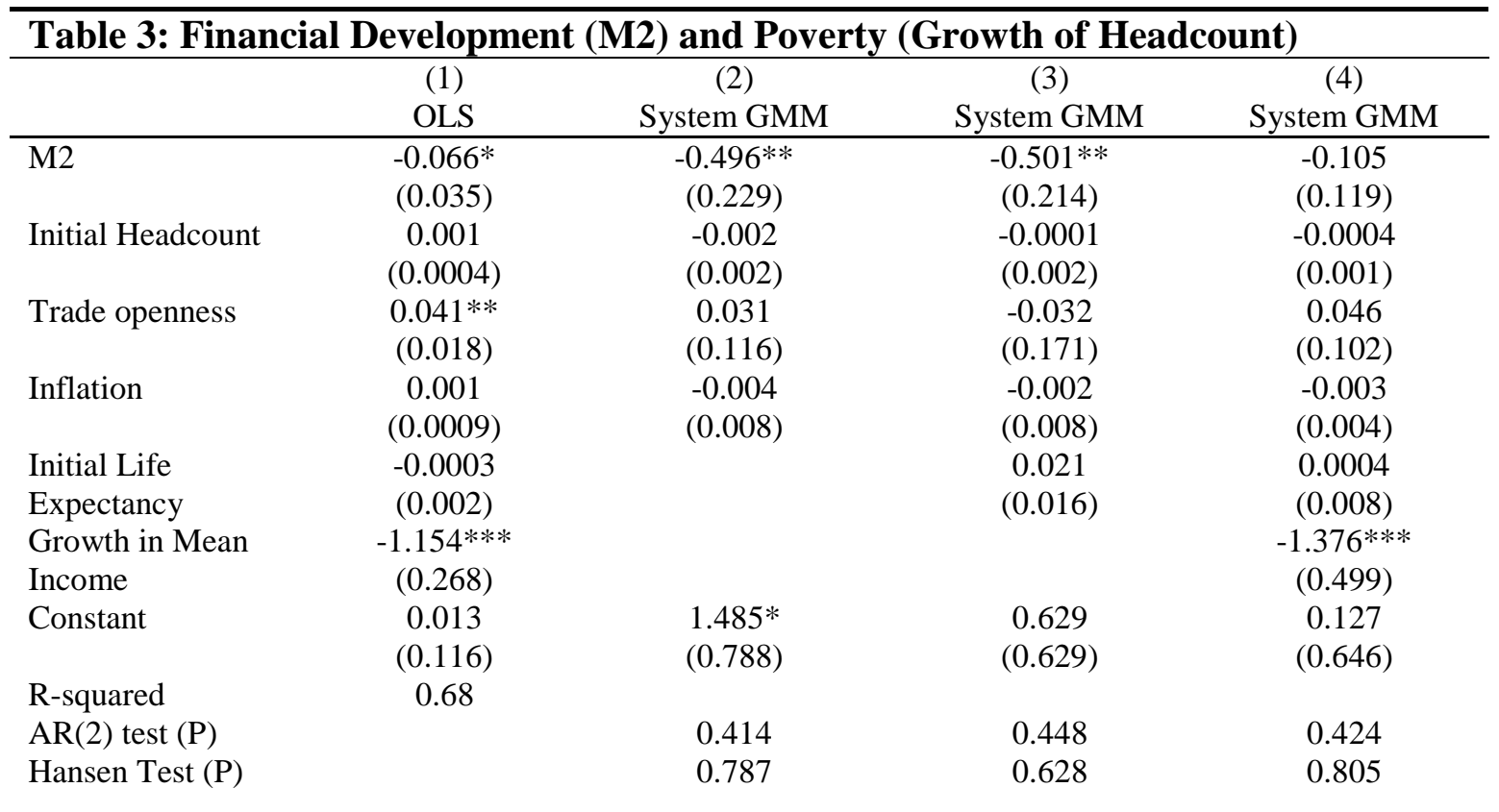

Note: The dependent variable is growth of headcount. ${ }^{* *},{ }^{* *},{ }^{*}$ indicate significance at the $1 \%, 5 \%$ and $10 \%$ levels respectively. Standard errors reported are Windmeijer corrected Standard errors. 


\begin{tabular}{lcccc}
\hline $\begin{array}{l}\text { Table 4: Financial Development (Private Credit) } \\
\text { Lowest Quintile) }\end{array}$ & \multicolumn{3}{l}{ and Poverty (Growth of Income of } \\
\hline & $(1)$ & $(2)$ & $(3)$ & $(4)$ \\
& OLS & System GMM & System GMM & System GMM \\
\hline Private Credit & -0.008 & -0.068 & -0.097 & -0.094 \\
& $(0.016)$ & $(0.058)$ & $(0.068)$ & $(0.106)$ \\
Initial Income of Lowest & $-0.091^{* * *}$ & $-0.133^{* *}$ & -0.108 & $-0.133^{* *}$ \\
Quintile & $(0.018)$ & $(0.068)$ & $(0.075)$ & $(0.068)$ \\
Trade openness & $9.08 \mathrm{E}-05$ & $0.156^{* *}$ & $0.224^{* *}$ & $0.205^{* * *}$ \\
& $(0.018)$ & $(0.067)$ & $(0.099)$ & $(0.082)$ \\
Inflation & -0.001 & $-0.006^{* * *}$ & $-0.007^{* * *}$ & $-0.005^{* *}$ \\
& $(0.001)$ & $(0.002)$ & $(0.002)$ & $(0.002)$ \\
Initial Life Expectancy & $-0.003^{* *}$ & -0.006 & -0.008 & -0.007 \\
& $(0.001)$ & 0.009 & $(0.014)$ & $(0.014)$ \\
Growth of Per Capita GDP & -0.254 & & $-0.153^{* *}$ & 0.386 \\
& $(0.218)$ & & $(0.072)$ & $(0.971)$ \\
Growth of Per Capita GDP & & & & 0.168 \\
$*$ Initial income & & & -1.01 & $(0.296)$ \\
Constant & -0.120 & -0.811 & $(0.773)$ & $(1.022$ \\
& $(0.109)$ & $(0.524)$ & & \\
R-squared & 0.66 & 0.142 & 0.158 & 0.184 \\
AR(2) test (P) & & 0.851 & 0.637 & 0.780 \\
Hansen Test (P) & & &
\end{tabular}

\begin{tabular}{|c|c|c|c|c|}
\hline \multicolumn{5}{|c|}{ Table 5: Financial Development (M2) and Poverty (Growth of Income of Lowest } \\
\hline & (1) & (2) & (3) & (4) \\
\hline & OLS & System GMM & System GMM & System GMM \\
\hline \multirow[t]{2}{*}{$\mathrm{M} 2$} & -0.053 & 0.125 & 0.072 & 0.064 \\
\hline & $(0.040)$ & $(0.096)$ & $(0.104)$ & (0.109) \\
\hline Initial Income of Lowest & $-0.096 * * *$ & $-0.168 * * *$ & $-0.154 * * *$ & $-0.158^{* * *}$ \\
\hline Quintile & $(0.024)$ & $(0.032)$ & $(0.034)$ & $(0.036)$ \\
\hline \multirow[t]{2}{*}{ Trade openness } & -0.034 & -0.123 & -0.064 & -0.052 \\
\hline & $(0.023)$ & (0.149) & $(0.108)$ & $(0.100)$ \\
\hline \multirow[t]{2}{*}{ Inflation } & -0.001 & -0.003 & -0.003 & -0.003 \\
\hline & $(0.001)$ & $(0.004)$ & $(0.003)$ & $(0.003)$ \\
\hline \multirow{2}{*}{ Initial Life Expectancy } & -0.002 & 0.003 & 0.0001 & -0.002 \\
\hline & $(0.002)$ & 0.015 & $(0.011)$ & $(0.012)$ \\
\hline \multirow[t]{2}{*}{ Growth of Per Capita GDP } & -0.093 & & -0.116 & 0.590 \\
\hline & $(0.243)$ & & $(0.104)$ & $(1.228)$ \\
\hline \multirow{2}{*}{$\begin{array}{l}\text { Growth of Per Capita GDP } \\
\text { * Initial income }\end{array}$} & & & & 0.228 \\
\hline & & & & $(0.387)$ \\
\hline \multirow[t]{2}{*}{ Constant } & -0.169 & -0.490 & -.389 & -0.329 \\
\hline & $(0.154)$ & $(0.492)$ & $(0.463)$ & $(0.541)$ \\
\hline R-squared & 0.52 & & & \\
\hline $\mathrm{AR}(2)$ test $(\mathrm{P})$ & & 0.226 & 0.170 & 0.265 \\
\hline Hansen Test $(\mathrm{P})$ & & 0.630 & 0.566 & 0.623 \\
\hline
\end{tabular}




\begin{tabular}{lcccc}
\hline \multicolumn{1}{l}{ Table 6: Financial Development (Private Credit) and Inequality (Gini Index) } & \\
\hline & $(1)$ & $(2)$ & $(3)$ & $(4)$ \\
& OLS & System GMM & System GMM & System GMM \\
\hline Private Credit & 0.003 & 0.024 & 0.010 & 0.037 \\
& $(0.009)$ & $(0.039)$ & $(0.033)$ & $(0.051)$ \\
Initial Gini & $-0.086^{* * *}$ & -0.061 & -0.075 & -0.089 \\
& $(0.021)$ & $(0.069)$ & $(0.092)$ & $(0.097)$ \\
Trade openness & -0.001 & $-0.086^{*}$ & $-0.128^{* *}$ & $-0.152^{* *}$ \\
& $(0.010)$ & $(0.049)$ & $(0.058)$ & $(0.064)$ \\
Inflation & 0.001 & $0.003^{* *}$ & $0.003^{* * *}$ & $0.004^{* *}$ \\
& $(0.001)$ & $(0.002)$ & $(0.001)$ & $(0.002)$ \\
Initial Life Expectancy & 0.001 & & 0.008 & 0.008 \\
& $(0.001)$ & & $(0.006)$ & $(0.007)$ \\
Growth of Per capita GDP & 0.138 & & & 0.045 \\
& $(0.123)$ & & & $0.468)$ \\
Growth of Per Capita GDP * & & & 0.013 \\
Initial Gini & & & 0.408 & $(0.144)$ \\
Constant & $0.255^{* * *}$ & $0.605^{*}$ & $(0.412)$ & 0.5722 \\
& $(0.090)$ & $(0.319)$ & & $(0.5948)$ \\
R-square & 0.54 & & 0.541 & 0.568 \\
AR(2) test (P) & & 0.422 & 0.851 & 0.633 \\
Hansen Test (P) & & 0.788 & & \\
\hline
\end{tabular}

Note: The dependent variable is growth of Gini index. ***, **, * indicate significance at the $1 \%, 5 \%$ and $10 \%$ levels respectively.

Standard errors reported are Windmeijer corrected Standard errors.

\begin{tabular}{lcccc}
\hline \multicolumn{1}{l}{ Table 7: Financial Development (M2) and Inequality (Gini Index) } & \\
\hline & $(1)$ & $(2)$ & $(3)$ & $(4)$ \\
& OLS & System GMM & System GMM & System GMM \\
\hline M2 & -0.026 & -0.040 & -0.018 & -0.003 \\
& $(0.020)$ & $(0.032)$ & $(0.040)$ & $(0.054)$ \\
Initial Gini & $-0.097^{* * *}$ & $-0.143^{* * *}$ & $-0.150^{* *}$ & $-0.146^{* *}$ \\
& $(0.025)$ & $(0.036)$ & $(0.061)$ & $(0.067)$ \\
Trade openness & 0.013 & 0.002 & -0.016 & 0.008 \\
& $(0.012)$ & $(0.001)$ & $(0.044)$ & $(0.054)$ \\
Inflation & 0.001 & $0.002^{*}$ & 0.002 & 0.001 \\
& $(0.001)$ & $(0.001)$ & $(0.001)$ & $0.001)$ \\
Initial Life Expectancy & 0.001 & & 0.004 & 0.002 \\
& $(0.001)$ & & $(0.003)$ & $(0.003)$ \\
Growth of Per capita GDP & 0.066 & & -0.163 \\
& $(0.124)$ & & & $(1.057)$ \\
Growth of Per Capita GDP * & & & & 0.054 \\
Initial Gini & & & & $(0.276)$ \\
Constant & $0.319^{* * *}$ & $0.628^{* * *}$ & $0.483^{*}$ & 0.423 \\
& $(0.107)$ & $(0.195)$ & $(0.291)$ & $(0.311)$ \\
R-square & 0.50 & & & \\
AR(2) test (P) & & 0.270 & 0.212 & 0.220 \\
Hansen Test (P) & & 0.755 & 0.771 & 0.843 \\
\hline
\end{tabular}

Note: The dependent variable is growth of Gini index. ${ }^{* * *},{ }^{* *}, *$ indicate significance at the $1 \%, 5 \%$ and $10 \%$ levels respectively.

Standard errors reported are Windmeijer corrected Standard errors. 


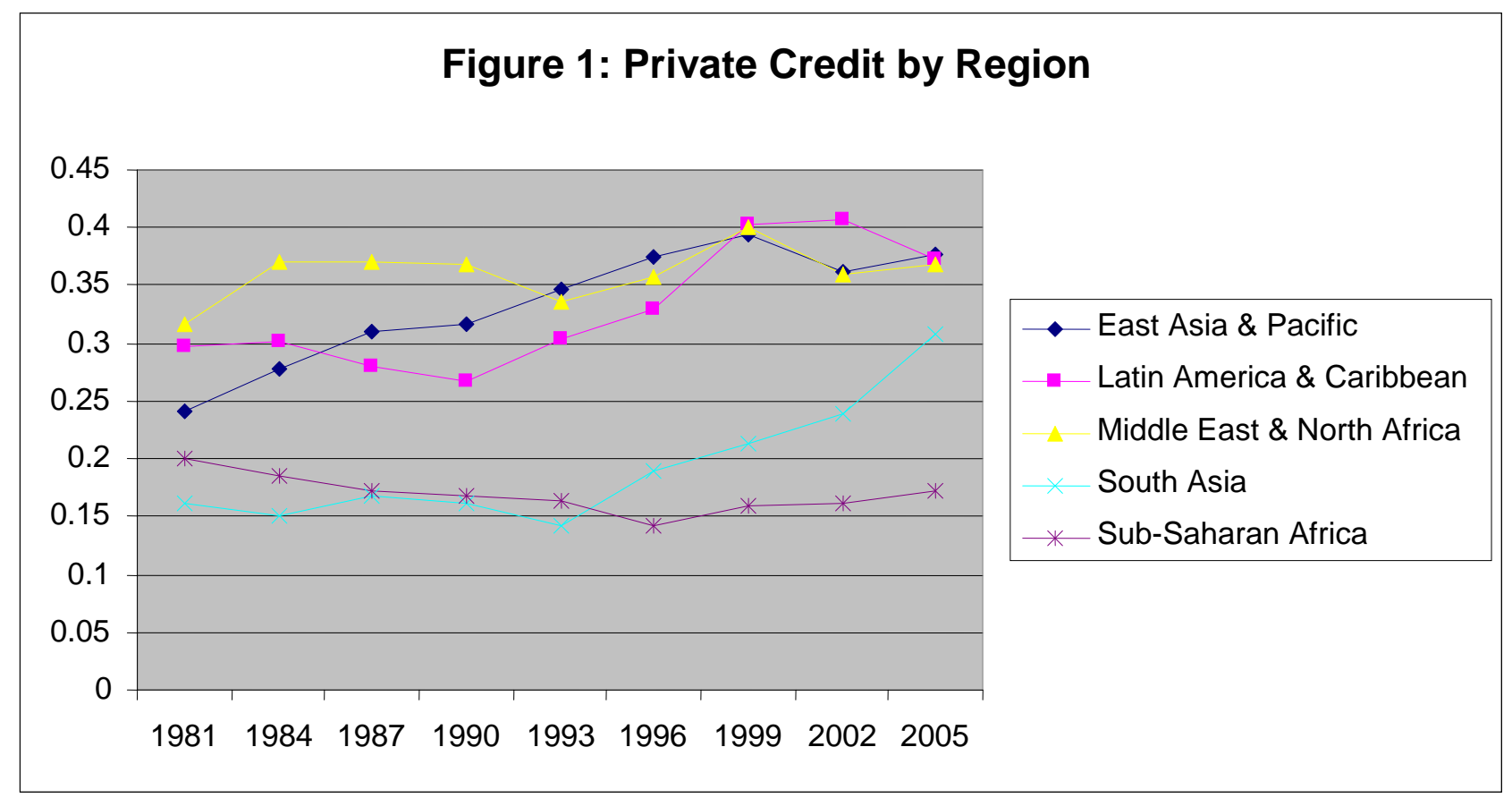

Source: Beck, Demirguc-Kunt and Levine (2007)

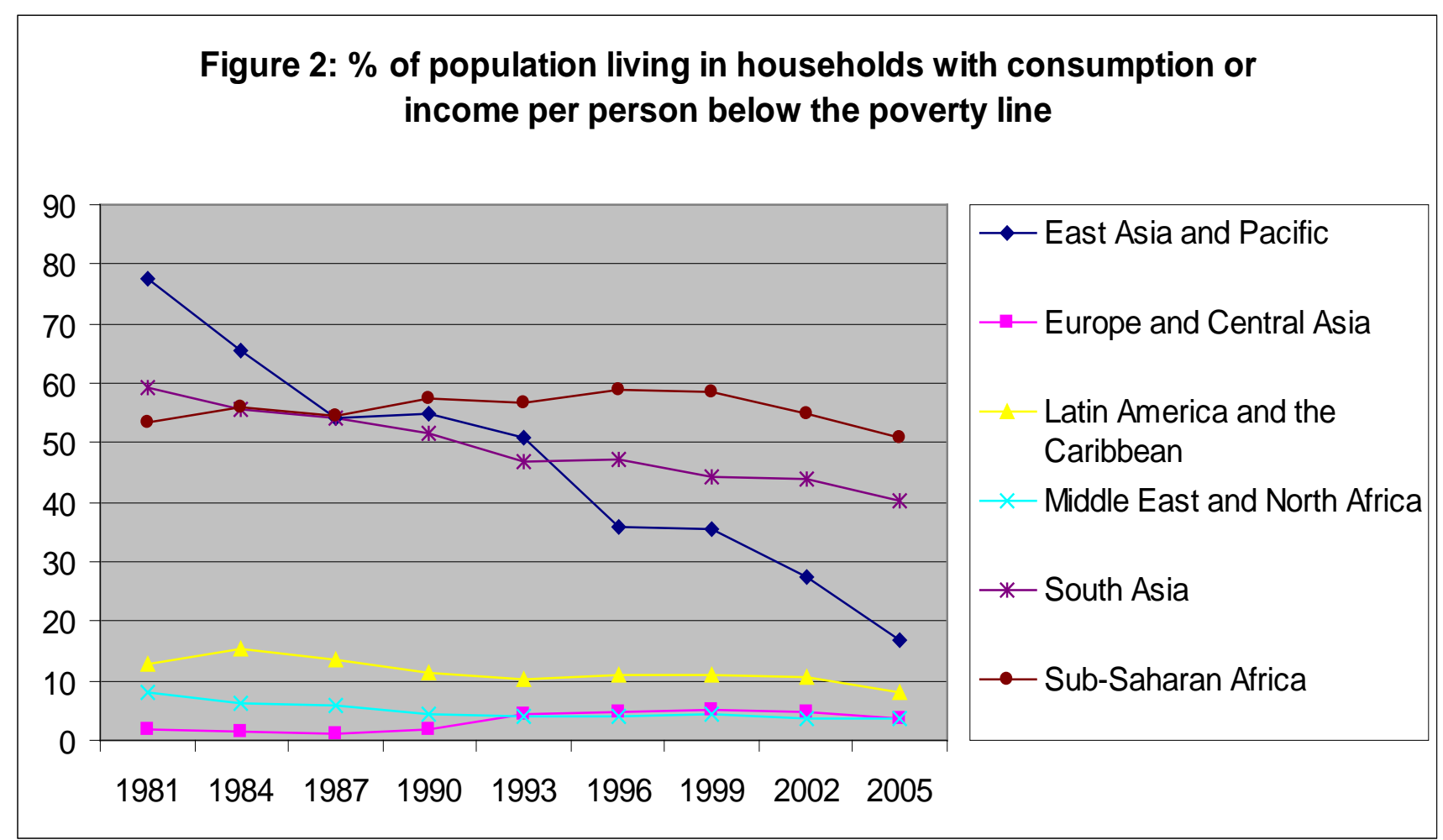

Source: World Bank website using polvcalnet. 


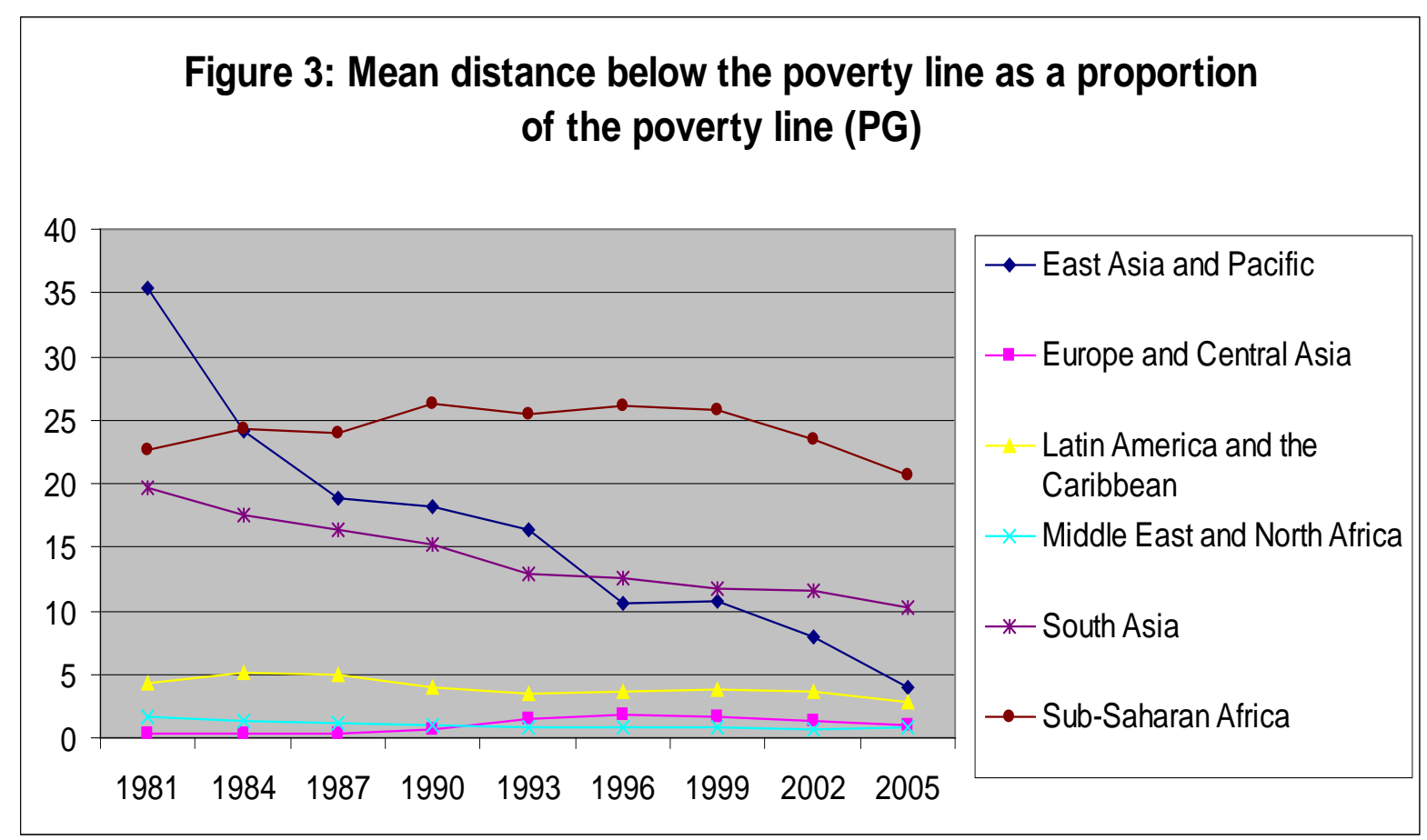

Source: World Bank website using polvcalnet. 